\title{
Analisis Kesulitan Siswa Kelas XI IA SMA Negeri 1 Tanah Jawa Dalam Menyelesaikan Soal-Soal Kelarutan Dan Hasil Kali Kelarutan
}

\author{
Fitri Anggraini ${ }^{1)}$, Jamalum Purba ${ }^{2)}$ \\ ${ }^{1)}$ Mahasiswa Pendidikan Kimia SPs UNIMED / STIKOM Tunas Bangsa \\ ${ }^{2)}$ Dosen Jurusan Kimia FMIPA UNIMED \\ e-mail : fitrianggraini@stikomtb.ac.id
}

\begin{abstract}
ABSTRAK
Penelitian deskriptif kuantitatif ini bertujuan untuk mengidentifikasi kesalahan-kesalahan yang dilakukan siswa dalam menyelesaikan soal-soal Kelarutan dan Hasil Kali Kelarutan, mengetahui letak kesalahan dominan dan penyebab kesalahan yang dilakukan siswa di kelas XI IA SMA Negeri 1 Tanah Jawa Tahun Pembelajaran 2012/2013. Kesalahan dominan terletak pada aplikasi Ksp (21,38\%). Setelah dilakukan pemberian perlakuan berupa My ChemNote, kesalahan yang dominan dilakukan siswa terletak pada tidak dapat membuat penyelesaian soal (26,5\%). Hal ini boleh jadi disebabkan karena keterbatasan waktu dalam menyelesaikan soal-soal kelarutan dan hasil kali kelarutan yang diberikan. Kesalahan lain yang mengalami peningkatan antara lain, konsep mol $(5,13 \%)$ dan pengendapan larutan $(8,55 \%)$. Kesalahan yang mengalami penurunan antara lain, hubungan konsep mol dengan persamaan Ksp (4,84\%), pengertian kelarutan $(0,57 \%)$, pengertian Ksp (3,42\%), larutan jenuh $(0 \%)$, aplikasi Ksp $(0,29 \%)$ dan kesalahan dalam operasi hitung $(8,83 \%)$.

Kata kunci : Analisis Kesulitan Siswa, My ChemNote, Kelarutan dan Hasil Kali Kelarutan.

\section{ANALYSIS OF DIFFICULTY CLASS XI IA SMA NEGERI 1 TANAH JAWA IN RESOLVING PROBLEMS SOLUBILITY AND SOLUBILITY PRODUCT}

\begin{abstract}
This quantitative descriptive research type aims to identify the mistakes that the students in solving problems of solubility and solubility product, know the location and cause of the dominant error mistakes made by students in class XI IA SMA Negeri 1 Tanah Jawa Learning Year 2012/2013. Dominant fault lies in the application Ksp (21.38\%). After the implementation of this form of My ChemNote, the dominant fault lies in the students, can't make the settlement question (26.5\%). This may be due to time limitations in solving the problems of solubility and solubility product is given. Errors are decreased, among other, the concept of moles $(5.13 \%)$ and the deposition solution $(8.55 \%)$. Errors which decreased among others, relations with the mole concept Ksp equations (4.84\%), understanding solubility (0.57\%), understanding Ksp (3.42\%), saturated solution (0\%), application Ksp (0, 29\%) and errors in arithmetic operations $(8.83 \%)$. Keywords : Difficulties Analysis Students, My ChemNote, Solubility And Solubility Product
\end{abstract}

\section{PENDAHULUAN}

"Kesulitan siswa dalam mempelajari Ilmu Kimia dapat bersumber pada kesulitan dalam istilah, kesulitan dalam memahami konsep kimia dan kesulitan angka" (Arifin, 1995). Dalam pelajaran kimia tidak terlepas dari perhitungan matematik, dimana siswa dituntut untuk terampil dalam rumusan/operasi matematika. Namun sering dijumpai siswa yang kurang memahami rumusan tersebut. Hal ini disebabkan karena siswa tidak mengetahui dasar-dasar matematik yang baik, siswa tidak hafal rumusan matematik yang banyak digunakan dalam perhitungan-perhitungan kimia, sehingga siswa tidak terampil dalam menggunakan operasi-operasi dasar matematik.

Selain itu, pada umumnya siswa sudah menganggap bahwa mata pelajaran kimia menakutkan dan membosankan, akibatnya tidak sedikit siswa yang kurang bahkan tidak tertarik dalam memahami dan menguasai konsep-konsep dasar materi kimia. Hal inilah yang tergambar di SMA Negeri 1 Tanah Jawa. Dengan Kriteria Ketuntasan Minimal (KKM) SMA Negeri 1 Tanah Jawa sebesar 70, sebagian besar siswa jurusan Ilmu Alam justru kurang memiliki ketertarikan terhadap materi pelajaran kimia dengan alasan yang beragam.

Kelarutan dan Hasil Kali Kelarutan yang merupakan salah satu materi kimia yang memiliki konsep dasar matematik dan memiliki konsep yang kompleks dan saling berhubungan satu sama lain. Pokok bahasan kelarutan dan hasil kali kelarutan merupakan salah satu materi yang dianggap sulit oleh siswa, karena pada 
pokok bahasan ini siswa dituntut untuk mampu menyelesaikan soal-soal perhitungan yang banyak menggunakan konsep-konsep tertentu, bukan hanya menggunakan perhitungan matematik, seperti kapan larutan dikatakan belum jenuh, tepat jenuh, lewat jenuh yang dibandingkan dengan harga tetapan hasil kali kelarutan dan koefisisen reaksinya, selain itu ada lagi yang dikatakan dengan pengaruh ion senama. Pada pokok bahasan ini diharapkan siswa harus lebih memahami konsep-konsep pembelajaran. Oleh karenanya, untuk membantu siswa dalam mengerjakan soal-soal Kelarutan dan Hasil Kali Kelarutan, perlu adanya identifikasi kesalahan dalam mengerjakan soal. Hal ini dilakukan agar dapat diberikan bimbingan yang tepat sehingga kemampuan siswa akan bertambah baik.

Penelitian mengenai pokok bahasan kelarutan dan hasil kali kelarutan ini sudah diteliti oleh Ginting (2011) yang menyatakan besarnya pengaruh model pembelajaran kooperatif tipe CIRC (Cooperatif Integreted Reading and Composition) terhadap peningkatan hasil belajar siswa sebesar 71,26\%, pada peneitian ini, peniliti terfokus pada penyelesaian soal-soal perhitungan berbentuk cerita. Penelitian yang diaksanakan Ginting (2012) menyatakan penerapan pendekatan kontruktivisme dengan model pembelajaran TAI (Team Assisted Individualization) dapat meningkatkan hasil belajar kimia siswa pada pokok bahasan kelarutan dan hasil kali kelarutan lebih tinggi (18\%) dibanding dengan pendekatan kontruktivisme tanpa model pembelajaran TAI (15\%).

Adapun kesulitan yang dimaksud dalam penelitian ini adalah kesulitan siswa-siswi SMA kelas XI IA semester Genap dalam menyelesaikan soal-soal Kelarutan dan Hasil Kali Kelarutan dikarenakan siswa tidak mengetahui cara atau metode yang tepat untuk menyelasaikan soal-soal Kelarutan dan Hasil Kali Kelarutan sehingga siswa tidak dapat menyelesaikan soal dengan benar ataupun tidak dapat menjawabnya sama sekali.

My ChemNote digunakan untuk membantu siswa mengingat ulang point-point penting atau point-point sulit dari sebuah materi pelajaran, terutama materi pelajaran yang telah lewat tetapi masih mendapat pengulang atau menjadi dasar pada materi berikutnya.

Dengan membuat rangkuman materi pelajaran yang sudah dipelajari, siswa dengan tidak langsung telah melakukan upaya memperkuat retensinya dan dalam waktu yang sama ia akan mempelajari kembali ateri (konsep, proedur atau prinsip) yang belum sepenuhnya dipahaminya. Dengan kata lain, dalam suatu proses pembelajaran, setelah eorang guru memberikan materi pembelajaran, diharapkan guru tersebut memberikan suatu rangkuman tentang pernyataan-pernyataan penting dari materi yang baru diajarkan, utnuk membantu siswa dalam memahami materi pembelajaran secara komprehensif, sehingga tujuan instruksional yang telah disusun sebelumnya dapat tercapai. Penyampaian rangkuman pada setiap proses pembelajaran merupakan salah satu tugas yang harus dilakukan oleh seorang guru (Hamidin, 2006).

Berdasarkan permasalahan diatas, maka penelitian ini bertujuan untuk memahami dan menyelidiki antara lain ; kesalahan-kesalahan dominan, penyebab kesalahan-kesalahan, dan implikasi dari penggunaan My ChemNote dalam mengatasi kesulitan tersebut yang dilakukan siswa kelas XI IA SMA Negeri 1 Tanah Jawa dalam menyelesaikan soal-soal Kelarutan dan Hasil Kali Kelarutan.

Hasil penelitian ini diharapkan dapat sebagai bahan masukan untuk mengetahui kesulitan-kesulitan siswa dalam menjawab soal-soal perhitungan kimia khususnya dalam menetukan kadar zat dalam suatu senyawa serta mengupayakan alternatif penyelesaian berupa My ChemNote untuk mengatasi kesulitankesulitan tersebut.

\section{METODE}

Penelitian dilaksanakan di SMA Negeri 1 Tanah Jawa, pada siswa kelas XI IA ${ }^{1}$ semester II tahun pelajaran 2012-2013. Waktu penelitian dalam bulan Mei 2013.

Sampel penelitian adalah siswa kelas XI IA SMA Negeri 1 Tanah Jawa yang telah mempelajari materi Kelarutan dan Hasil Kali Kelarutan. Dimana dari 3 kelas XI IA diambil 1 kelas secara Purposif dengan total 39 siswa sebagai sampel penelitian.

Metode yang diterapkan dalam penelitian ini berbentuk deskriptif kualitatif yang mengamati suatu fenomena dan menggambarkannya apa adanya. Sesuai dengan metode yang dipakai, maka analisis kualitatif akan digunakan untuk menjelaskan fenomena yang dimaksud, dalam hal ini, analisis kesalahan siswa dalam menyelesaikan soal-soal Kelarutan dan Hasil Kali Kelarutan. Analisis dokumen berupa jawaban-jawaban siswa tentang soal-soal yang berhubungan dengan Kelarutan dan Hasil Kali Kelarutan akan dilaksanakan dengan mengklasifikasi obyek temuan secara kualitatif untuk menyelidiki kesalahan dominan yang dilakukan siswa dengan memprediksikan penyebab kesalahan tersebut. Setelah dipresdiksi penyebab 
kesalahan tersebut, kemudian dilakukan treatment kepada siswa dengan membimbing siswa bagaimana cara menyelesaikan soal dengan benar kemudian siswa akan merangkumnya sendiri dalam My ChemNote yang telah dibagikan sebelumnya. Setelah diberikan treatment dilakukan pemberian instrumen tes kembali dan membandingkan hasilnya dengan sebelum diberi treatment.

Instrumen yang digunakan berupa instrument Tes dengan 10 butir soal mengenai materi pokok Kelarutan dan Hasil Kali Kelarutan dalam bentuk uraian dan instrument wawancara.

Dalam penelitian ini akan diungkapkan kealahan-kesalahan siswa dalam menyelesaikan soal-soal pokok bahasan Kelarutan dan Hasil Kali Kelarutan yang diklasifikasikan ke dalam beberapa kriteria, yaitu sebagai berikut:

Tabel 3.1 Kategori Kesalahan Siswa

\begin{tabular}{c|l}
\hline Kategori & \multicolumn{1}{|c}{ Kriteria } \\
\hline A & Tidak dapat membuat penyelesaian soal \\
B & Kesalahan siswa dalam konsep pra-syarat \\
C & Kesalahan dalam konsep Kelarutan dan Hasil Kali Kelarutan \\
D & Kesalahan dalam operasi hitung \\
\hline
\end{tabular}

Untuk memudahkan dalam menganalisis data digunakan langkah-langkah sebagai berikut :

1. Memeriksa lembar jawaban

2. Mengelompokkan kesalahan-kesalahan siswa ke dalam salah satu kategori kesalahan (kategori A, B, C, dan D)

3. Mewawancarai beberapa orang siswa untuk mengetahui dan menangkap secara langsung seluruh informasi dari subjek penelitian. Wawancara dilakukan terhadap siswa yang menjadi subjek penelitian, 2 siswa yang paling banyak melakukan kesalahan dari setiap butir soal.

4. Menampilkan data yang didapat dengan menggunakan tabel yang mengelompokkan kriteria kesalahan siswa-siswi dalam menyelesaikan soal-soal perhitungan kimia (kategori A, B, C dan D), serta penyebab kesalahannya.

5. Menampilkan data berupa besar kesalahan siswa pada setiap kategori dengan menggunakan tabel. Setelah diketahui jumlah kesalahan siswa pada setiap kategori, maka dicari rata-rata kesalahan siswa (K) pada setiap kriteria dengan rumus:

$$
\mathrm{K}=\frac{\text { jumlah kesalahan siswa pada setiap kategori }}{\text { banyak soal }}
$$

6. Dan mencari presentase kesalahan siswa $(\% \mathrm{~K})$ pada setiap kategori dengan rumus :

$$
\% \mathrm{~K}=\frac{K}{\text { Jumlah Siswa }} \times 100 \%
$$

7. Menentukan kesalahan dominan yang dilakukan siswa berdasarkan persentase kesalahan siswa (\% K) yang terbesar

8. Memberikan treatment kepada siswa berupa pengulangan pembahasan soal yang dianggap susah dengan bantuan My ChemNote sebagai media catatan

9. Memberikan remedial soal kepada siswa

10. Menghitung kembali jumlah $\mathrm{K}$ dan $\% \mathrm{~K}$ setelah diberikan treatment dan membandingkannya dengan sebelum diberikan treatment

11. Memberikan kesimpulan dan saran

\section{HASIL DAN PEMBAHASAN}

\section{Hasil Penelitian}

Hasil penelitian disajikan berdasarkan jawaban siswa terhadap soal-soal yang diberikan, yaitu meliputi kemampuan siswa dan kesalahan siswa dominan dalam menyelesaikan soal-soal Kelarutan dan Hasil Kali Kelarutan serta hasil wawancara yang dilakukan.

Untuk melihat tingkat kemampuan masing-masing siswa dalam menyelesaikan soal-soal Kelarutan dan Hasil Kali Kelarutan, dilihat dari pencapaian skor masing-masing siswa pada Tes Awal yang disajikan dalam tabel 4.1 berikut: 
Tabel 4.1 Skor Kemampuan Siswa pada Tes Awal

\begin{tabular}{|c|c|c|c|c|c|}
\hline No & Nama Siswa & Skor & No & Nama Siswa & Skor \\
\hline 1 & Arie Mulyani Supraptiwi & 14 & 21 & Mangiring Simangunsong & 19 \\
\hline 2 & Cahaya M. Pasaribu & 20 & 22 & Mindo Sibuea & 18 \\
\hline 3 & Chatrin N. Simatupang & 12 & 23 & Nico Andreas P & 16 \\
\hline 4 & Christin Masniari Siregar & 17 & 24 & Nurhayani Sinurat & 13 \\
\hline 5 & Coky F.L Simanjuntak & 21 & 25 & Oktavina Olivia Purba & 18 \\
\hline 6 & Desry M. Matondang & 14 & 26 & Paula M.R. Sinaga & 17 \\
\hline 7 & Dewi Fransiska & 14 & 27 & Puteri Utami Jane & 17 \\
\hline 8 & Dimas Prayogo & 20 & 28 & Rusmaida & 15 \\
\hline 9 & Eko Reynaldo S & 24 & 29 & Satrina Pangaribuan & 18 \\
\hline 10 & Epri Wismark & 23 & 30 & Saut Sejali Sauhur Hutapea & 24 \\
\hline 11 & Ernawati Ambarita & 15 & 31 & Segara Kinasih Sagala & 15 \\
\hline 12 & Frydo San Hery & 23 & 32 & Septima L.S Napitu & 19 \\
\hline 13 & Goodman Tampubolon & 21 & 33 & Sri Novalita & 19 \\
\hline 14 & Hotmian Sitorus & 13 & 34 & Suhendro S. Purba & 19 \\
\hline 15 & Ilham Ade Putra & 25 & 35 & Suria Atningsih & 21 \\
\hline 16 & Imam Nawawi & 20 & 36 & Trimas Manalu & 22 \\
\hline 17 & Ira E.F Gultom & 16 & 37 & Try Putra S & 22 \\
\hline 18 & Junirman Laoli & 23 & 38 & Widya Butar-Butar & 21 \\
\hline 19 & Junjun Wijaya & 24 & 39 & Yayuk Nurjanah & 17 \\
\hline 20 & Lika Julianta Siregar & 18 & & & \\
\hline
\end{tabular}

Dari hasil tabulasi 39 siswa diperoleh:

Tabel 4.2 Persentase Skor Siswa pada Tes Awal

\begin{tabular}{c|c|c}
\hline Range Skor & Siswa & Persentase $(\%)$ \\
\hline $12-16$ & 11 & 28.21 \\
$17-20$ & 15 & 38.46 \\
$21-25$ & 13 & 33.33 \\
\hline
\end{tabular}

Skor kemampuan rata-rata siswa diperoleh 18,64 dari skor maksimum 45. Jika dikonversikan ke nilai, nilai rata-rata siswa sebesar 41,42 pada skala 1-100.

Setelah diberi perlakuan/treatment berupa pengulangan dengan menggunakan My ChemNote maka diadakan pemberian tes ulang dan diperoleh:

Tabel 4.3 Skor Kemampuan Siswa pada Tes Akhir

\begin{tabular}{c|l|l|c|l|l}
\hline No & Nama Siswa & Skor & No & \multicolumn{1}{|c}{ Nama Siswa } & Skor \\
\hline 1 & Arie Mulyani Supraptiwi & 27 & 21 & Mangiring Simangunsong & 25 \\
2 & Cahaya M. Pasaribu & 22 & 22 & Mindo Sibuea & 19 \\
3 & Chatrin N. Simatupang & 29 & 23 & Nico Andreas P & 20 \\
4 & Christin Masniari Siregar & 13 & 24 & Nurhayani Sinurat & 26 \\
5 & Coky F.L Simanjuntak & 30 & 25 & Oktavina Olivia Purba & 29 \\
6 & Desry M. Matondang & 22 & 26 & Paula M.R. Sinaga & 22 \\
7 & Dewi Fransiska & 25 & 27 & Puteri Utami Jane & 25 \\
8 & Dimas Prayogo & 28 & 28 & Rusmaida & 34 \\
9 & Eko Reynaldo S & 29 & 29 & Satrina Pangaribuan & 28 \\
10 & Epri Wismark & 31 & 30 & Saut Sejali Sauhur Hutapea & 25 \\
11 & Ernawati Ambarita & 26 & 31 & Segara Kinasih Sagala & 29 \\
12 & Frydo San Hery & 37 & 32 & Septima L.S Napitu & 20 \\
13 & Goodman Tampubolon & 31 & 33 & Sri Novalita & 30 \\
14 & Hotmian Sitorus & 25 & 34 & Suhendro S. Purba & 26 \\
15 & Ilham Ade Putra & 40 & 35 & Suria Atningsih & 21 \\
16 & Imam Nawawi & 26 & 36 & Trimas Manalu & 28
\end{tabular}




\begin{tabular}{l|l|l|l|l|l}
17 & Ira E.F Gultom & 31 & 37 & Try Putra S & 35 \\
18 & Junirman Laoli & 30 & 38 & Widya Butar-Butar & 21 \\
19 & Junjun Wijaya & 24 & 39 & Yayuk Nurjanah & 29 \\
\cline { 3 - 5 } 20 & Lika Julianta Siregar & 28 & &
\end{tabular}

Dari hasil tabulasi 39 siswa diperoleh:

Tabel 4.4 Persentase Skor Siswa pada Tes Akhir

\begin{tabular}{c|c|c}
\hline Range Skor & Siswa & Persentase $(\%)$ \\
\hline $13-22$ & 9 & 23,08 \\
$23-30$ & 23 & 58,97 \\
$31-40$ & 7 & 17,95 \\
\hline
\end{tabular}

Setelah diberikan perlakuan berupa pengulangan dengan My ChemNote, diperoleh skor kemampuan rata-rata siswa sebesar 26,82 dari skor maksimum 45. Jika dikonversikan ke nilai, nilai rata-rata siswa sebesar 59,60 pada skala 1-100.

Tabel 4.5 Persentase Perbandingan Skor dan Nilai pada Sebelum dan Sesudah Perlakuan

\begin{tabular}{c|c|c|c}
\hline \multirow{2}{*}{$\begin{array}{c}\text { Rata- } \\
\text { rata }\end{array}$} & \multicolumn{2}{|c|}{ Perlakuan } & \multirow{2}{*}{ Peningkatan (\%) } \\
\cline { 2 - 3 } & Sebelum & Sesudah & \\
\hline Skor & 18.64 & 26.82 & $8 \%$ \\
Nilai & 41.42 & 59.60 & $18 \%$ \\
\hline
\end{tabular}
yaitu:

Berdasarkan tabulasi dari jawaban-jawaban siswa, diperoleh jumlah kesalahan pada setiap kategori,

1. Kategori A : 66

2. Kategori B :

Meliputi : - Konsep Mol $=12$

- Menghubungkan konsep mol dengan persamaan Ksp= 39

3. Kategori C :

Meliputi : - Pengertian Kelarutan

- Pengertian Ksp

$=4$

- Larutan Jenuh

$=4$

- Pengendapan Larutan

$=19$

- Aplikasi Ksp

$=15$

4. Kategori D : 66

$=75$

Untuk mengetahui persentase letak kesulitan siswa, maka dihitung persentase kesulitan siswa dalam menjawab soal-soal Kelarutan dan Hasil Kali Kelarutan yang disajikan pada tabel 4.16.

Tabel 4.16 Persentase Letak Kesulitan Siswa pada Tes Awal

\begin{tabular}{c|l|c|c|c}
\hline No & \multicolumn{1}{|c|}{ Letak Kesulitan } & $\begin{array}{c}\text { Jumlah } \\
\text { Kesalahan }\end{array}$ & $\mathrm{K}$ & $\% \mathrm{~K}$ \\
\hline 1 & Tidak memahami soal & 66 & 7.33 & 18.80 \\
\hline 2 & Konsep Mol & 12 & 1.33 & 3.42 \\
\hline 3 & Hubungan konsep mol dengan persmaan Ksp & 39 & 4.33 & 11.11 \\
\hline 4 & Pengertian kelarutan & 4 & 0.44 & 1.14 \\
\hline 5 & Pengertian Ksp & 4 & 0.44 & 1.14 \\
\hline 6 & Larutan Jenuh & 19 & 2.11 & 5.41 \\
\hline 7 & Pengendapan Larutan & 15 & 1.66 & 4.27 \\
\hline 8 & Aplikasi Ksp & 75 & 8.33 & 21.38 \\
\hline 9 & Kesalahan dalam Operasi Hitung & 66 & 7.33 & 18.80 \\
\hline
\end{tabular}

Berdasarkan tabulasi dari jawaban-jawaban siswa, diperoleh jumlah kesalahan pada setiap kategori, yaitu:

1. Kategori A : 93

2. Kategori B :

Meliputi : - Konsep Mol

$=18$ 
- Menghubungkan konsep mol dengan persamaan Ksp = 17

3. Kategori $\mathrm{C}$ :

Meliputi : - Pengertian Kelarutan

- Pengertian Ksp

$=2$

- Larutan Jenuh

$=12$

- Pengendapan Larutan

$=0$

- Aplikasi Ksp

\section{Kategori D : 31}

$$
=30
$$

$=1$

Untuk mengetahui persentase letak kesulitan siswa, maka dihitung persentase kesulitan siswa dalam menjawab soal-soal Kelarutan dan Hasil Kali Kelarutan yang disajikan pada tabel 4.27.

Tabel 4.27 Persentase Letak Kesulitan Siswa pada Tes Akhir

\begin{tabular}{c|l|c|c|c}
\hline No & \multicolumn{1}{|c|}{ Letak Kesulitan } & $\begin{array}{c}\text { Jumlah } \\
\text { Kesalahan }\end{array}$ & $\mathrm{K}$ & \% K \\
\hline 1 & Tidak memahami soal & 93 & 10.33 & 26.5 \\
\hline 2 & Konsep Mol & 18 & 2 & 5.13 \\
\hline 3 & Hubungan konsep mol dengan persmaan Ksp & 17 & 1.89 & 4.84 \\
\hline 4 & Pengertian kelarutan & 2 & 0.22 & 0.57 \\
\hline 5 & Pengertian Ksp & 12 & 1.33 & 3.42 \\
\hline 6 & Larutan Jenuh & 0 & 0 & 0 \\
\hline 7 & Pengendapan Larutan & 30 & 3.33 & 8.55 \\
\hline 8 & Aplikasi Ksp & 1 & 0.11 & 0.29 \\
\hline 9 & Kesalahan dalam Operasi Hitung & 31 & 3.44 & 8.83 \\
\hline
\end{tabular}

Setelah diketahui $\% \mathrm{~K}$ dari Tes Awal dan Tes Akhir, maka dapat dibandingkan perbedaan besar \% sebagai berikut :

Tabel 4.28 Perbandingan \%K pada Tes Awal dan Tes Akhir

\begin{tabular}{c|l|c|c|c|c}
\hline \multirow{2}{*}{ No Letak Kesulitan } & \multicolumn{2}{c|}{ Tes Awal } & \multicolumn{2}{c}{ Tes Akhir } \\
\cline { 3 - 6 } & & $\mathrm{K}$ & $\% \mathrm{~K}$ & $\mathrm{~K}$ & $\% \mathrm{~K}$ \\
\hline 1 & Tidak memahami soal & 7.33 & 18.8 & 10.33 & 26.5 \\
\hline 2 & Konsep Mol & 1.33 & 3.42 & 2 & 5.13 \\
\hline 3 & Hubungan konsep mol dengan persmaan Ksp & 4.33 & 11.11 & 1.89 & 4.84 \\
\hline 4 & Pengertian kelarutan & 0.44 & 1.14 & 0.22 & 0.57 \\
\hline 5 & Pengertian Ksp & 0.44 & 1.14 & 1.33 & 3.42 \\
\hline 6 & Larutan Jenuh & 2.11 & 5.41 & 0 & 0 \\
\hline 7 & Pengendapan Larutan & 1.66 & 4.27 & 0.33 & 8.55 \\
\hline 8 & Aplikasi Ksp & 8.33 & 21.38 & 0.11 & 0.29 \\
\hline 9 & Kesalahan dalam Operasi Hitung & 7.33 & 18.8 & 3.44 & 8.83 \\
\hline
\end{tabular}

Dari data yang ditampilkan pada tabel persentase letak kesulitan siswa pada tes awal dan tes akhir, diperoleh beberapa kesalahan yang dilkaukan siswa dalam meyelesaikan soal-soal Kelarutan dan Hasil Kali Kelarutan, antara lain:

1. Kesulitan pada kategori A, yaitu: Kesulitan dalam memahami kalimat soal, sehingga tidak ada penyelesaian soal.

2. Kesulitan pada kategori B, yaitu: Kesulitan dalam konsep pra syarat Kelarutan dan Hasil Kali Kelarutan, meliputi:

a. Kesalahan dalam pengertian Molaritas yang di hubungkan dengan pengertian Kelarutan.

b. Kesalahan dalam menghubungkan konsep mol dengan persamaan tetapan hasil kali kelarutan.

3. Kesulitan pada kategori C, yaitu: kesulitan dalam konsep Kelarutan dan Hasil Kali Kelarutan, meliputi:

a. Kesalahan dalam pengertian kelarutan

b. Kesalahan dalam pengertian Tetapan Hasil Kali Kelarutan 
c. Kesulitan dalam menjelaskan keadaan setimbang yang terjadi dalam suatu larutan jenuh, dimana kebanyakan jawaban yang salah adalah penjelasan bagaimana keadaan suatu larutan dikatakan belum jenuh, tepat jenuh dan lewat jenuh.

d. Kesulitan dalam menentukan perbedaan keadaan jenuh dalam suatu larutan denan syarat-syarat pembentukan endapan.

e. Kesulitan dalam aplikasi Ksp, antara lain seperti kesalahan dalam menentukan Ksp dan yang paling dominan dilakukan siswa adalah Kesalahan konsep dalam menentukan persamaan tetapan hasil kali kelarutan.

4. Kesulitan pada kategori D, yaitu kesulitan dalam operasi hitung.

\section{Pembahasan}

Berdasarkan uraian kesalahan-kesalahan yang dilakukan siswa dalam menyelesaikan soal-soal kelarutan dan hasil kali kelarutan, menunjukkan bahwa siswa mengalami kesulitan dalam menyelesaikan soal-soal kelarutan dan hasil kali kelarutan yang diberikan. Ini dapat dilihat dari tingkat kemampuan siswa dengan skor awal rata-rata 18,64 dari skor maksimal 45.

Tingkat kemampuan ini dikategorikan sangat rendah dan jauh dari ketuntasan belajar dalam menyelesaikan soal-soal kelarutan dan hasil kali kelarutan yang diberikan. Setelah diberikan perlakuan berupa pengulangan pembahasan materi kelarutan dan hasil kali kelarutan dengan media catatan My ChemNote, kemudian dilakukan tes ulang, diperoleh peningkatan skor menjadi 26,82 dari rata-rata skor awal sebesar 18,64, atau naik $8 \%$ dari rata-rata skor awal. Peningatan skor ini memenuhi 59,6\% dari skor maksimum 45, dan mendekati ketuntasan belajar dalam menyelesaikan soal-soal kelarutan dan hasil kali kelarutan.

Dengan dipaparkannya kesulitan-kesulitan yang dialami siswa saat mengerjakan soal-soal kelarutan dan hasil kali kelarutan, dari tes awal sampai tes akhir, diperoleh bahwa kesalahan dominannya berubah. Pada tes awal, yang menjadi kesalahan dominan adalah kesalahan pada kategori C, pada aplikasi Ksp dengan $\% \mathrm{~K}$ sebesar $21.38 \%$. Pada tes akhir, yang menjadi kesalahan dominan adalah kesalahan pada kategori A, tidak dapat membuat penyelesaian soal dengan $\% \mathrm{~K}$ sebesar $26.5 \%$. keadaan ini boleh jadi disebabkan karena waktu pengerjaan soal yang sempit dikarenakan keadaan proses belajar mengajar yang sedikit terganggu dari jadwal yang seharusnya, sehingga banyak siswa yang belum menyelesaikan jawabannya.

Dari pemaparan analisis kesulitan kesulitan siswa dalam menyelesaikan soal-soal kelarutan dan hasil kali kelarutan di atas, terlihat bahwa yang menjadi kesulitan dominan bagi siswa adalah pada pemahaman konsep kelarutan dan hasil kali kelarutan, hal ini terlihat pada tes awal bahwa persentase kesulitan pada kategori $\mathrm{C}$ yang paling tinggi. Maka dari hal ini, menjadi masukan bagi para pendidik untuk lebih memberikan penekanan pada ketegori-kategori yang telah dipaparkan sebelumnya dalam proses belajar mengajar kedepannya.

Kesalahan pada kategori D juga penting, karena saat konsep dan pemahaman telah tepat, tetapi terdapat kesalahan dalam operasi hitungan juga dapat mengurangi nilai. Walaupun tidak semua soal-soal kelarutan dan hasil kali kelarutan menggunakan penyelesaian matematika yang rumit, namun kemampuan mateatika sederhana seperti mengakar pangkat, bisa menjadi kesalahan dalam menentukan jawaban yang sebenarnya. Kesalahan pada kategori D ini memberikan persentase K sebesar $18.8 \%$ pada tes awal dan menurun menjadi $8.83 \%$ pada tes akhir. Hal ini perlu menjadi perhatian khusus pada saat proses belajar mengajar berlangsung, baik dalam proses belajar mengajar materi kimia ataupun terkhusus pada materi matematika.

Kesalahan yang sudah menjadi dasar dalam memulai materi kelarutan dan hasil kali kelarutan adalah kesalahan konsep pra syarat mengenai persamaan tetapan hasil kali kelarutan yang dianggap sama penulisannya dengan persamaan reaksi kesetimbangan. Untuk beberapa soal dengan menggunakan senyawa dengan muatan netral, seperti $\mathrm{MgCl}$, mungkin ini tidak terlalu berpengaruh, namun untuk soal dengan menggunakan senyawa dengan ion didalamnya, seperti $\mathrm{MgF}_{2}$, ini akan mempengaruhi jumlah $\mathrm{s}$ dan harga Ksp yang ditentukan. Karena salah dalam menentukan persamaan tetapan hasil kali kelarutannya.

Berdasarkan tujuan penelitian dan analisis data penelitian dapat disimpulkan bahwa kesalahan dominan yang dilakukan siswa kelas XI IA SMA Negeri 1 Tanah Jawa dalam menyelesaikan soal-soal Kelarutan dan Hasil Kali Kelarutan terletak pada Aplikasi Ksp sebesar 21,38\% dan tidak dapat membuat penyelesaian sebesar 26,5\%. 
Penyebab kesalahan-kesalahan siswa kelas XI IA SMA Negeri 1 Tanah Jawa dalam menyelesaikan soalsoal Kelarutan dan Hasil Kali Kelarutan antara lain dikerenakan siswa kurang memahami konsep dalam materi Kelarutan dan Hasil Kali Kelarutan seperti perbedaan persamaan reaksi kesetimbangan dengan persamaan tetapan hasil kali kelarutan sehingga salah dalam menentukan s dan Ksp nya serta kurang terampil dalam operasi matematika.

Implikasi dari penggunaan My ChemNote dalam mengatasi kesulitan-kesulitan siswa kelas XI IA SMA Negeri 1 Tanah Jawa dalam menyelesaikan soal-soal Kelarutan dan Hasil Kali Kelarutan dapat dilihat dari peningkatan skor rata-rata siswa dari 18,64 menjadi 26,82, peningkatan sebesar 8\%. Juga dapat dilihat dari menurunkan $\% \mathrm{~K}$ dominan dari $21,38 \%$ menjadi $0,29 \%$.

\section{DAFTAR PUSTAKA}

Ahmadi, A., Supriono, W., (2004), Psikologi Belajar, Penerbit Rineka Cipta, Jakarta.

Arifin, M., (1995), Pengembangan Program Pengajaran Kimia, Universitas Airlangga, Surabaya.

Arikunto, S., (2006), Prosedur Penelitian Suatu Pendekatan Praktik, Penerbit Rineka Cipta, Jakarta.

Ashadi, (2009), Kesulitan Belajar Kimia Bagi Siswa Sekolah Menengah.UPT Perpustakaan UNS. http://pdii.lipi.go.id/admin/jurnal/61086974.pdf. Diakses 08 Februari 2013.

Daryanto, (2010), Belajar dan Mengajar, Penerbit Yrama Widya, Bandung.

Dimyati dan Mudjiono, (2009), Belajar dan Pembelajaran, Penerbit Rineka Cipta, Jakarta.

Ginting, S.D., (2011), Pengaruh Model Pembelajaran Koopeartif Tipe Circ (Cooperative Integrated Reading And Compotition) Terhadap Kemamuan Siswa Dalam Menyelesaikan Soal Kimia Berbentuk Cerita Pada Pokok Bahasan Kelarutan Dan Hasil Kali Kelarutan., Skripsi, FMIPA, Unimed, Medan.

Ginting, K., (2012), Pengaruh Pendekatan Kontruktivisme Dengan Model Pembelajaran Tai (Team Assisted Individualization) Terhadap Peningkatan Hasil Belajar Siswa Pada Pokok Bahasan Kelarutan Dan Hasil Kali Kelarutan., Skripsi, FMIPA, Unimed, Medan.

Hamidin, (2006), Tesis : Pengaruh Metode Pemberian Rangkuman dan Sikap Beragama Terhadap Hasil Belajar Pendidikan Agama Islam Ssiwa SMA Negeri 1 Lawe Sigala-gala. Pps UNIMED, Medan.

Ihsan, M., (2010), Analisis Kesulitan Siswa Menjawab Soal-Soal Kesetimbangan Kimia,. Skripsi, FMIPA, Unimed, Medan.

Lestari, M., (2012), Perbandingan Model Pembelajaran Kooperatif Tipe Tai Dan Pembelajaran Aktif Tipe Quiz Team Terhadap Hasil Belajar Kimia Siswa SMA,. Skripsi, FMIPA, Unimed, Medan.

Marpaung, D., (2006), Hubungan Antara Kemampuan Membuat Rangkuman dan Minat Membaca dengan Kemampuan Menemukan Gagasan Pokok Siswa SMA Swasta Medan Tahun Pelajaran 2004-2005., Tesis, Pps Unimed, Medan.

Milfayetty, S., dkk, (2011), Psikologi Pendidikan, PPs UNIMED, Medan.

Muchtaridi, S.J., (2007), Kimia SMA Kelas XI, Penerbit Yudhistira, Bandung.

Pannen, P., Mustafa, D., Mestika, S., (2001), Kontruktivisme dalam Pembelajaran. PAU-PPAI Direktorat Jendral Pendidikan Tinggi Dekdiknas, Jakarta.

Purba, M., (2006), Kimia untuk SMA kelas XI, Penerbit Erlangga, Jakarta.

Rahmat, J., (1996), Psikologi Komunikasi, Penerbit ITB, Bandung.

Rusydie, S., (2011), Prinsip-Prinsip Manajemen Kelas, Penerbit DIVA Press, Jogjakarta.

Sagala, S., (2009), Konsep dan Makna Pembelajaran, Penerbit Alfabeta, Bandung.

Silitonga, P.M., (2011), Metodologi Penelitian Pendidikan. FMIPA UNIMED, Medan.

Sudjana, (2005), Metode Statistik, Penerbit Tarsito, Jakarta.

Sugiharti, G., (2008), Pengaruh Penggunaan Media Kartu Kuantum Terhadap Peningakatan Hasil Belajar Kimia Siswa. Jurnal Pendidikan Matematika dan Sains. 3 (1) : 9-13. http://pdii.lipi.go.id/admin/jurnal/31008913.pdf. (diakses 06 Pebruari 2013)

Tim Pengajar Matakuliah Perkembangan Peserta Didik, (2011), Perkembangan Peserta Didik, UNIMED, Medan.

Warsita, B., 2008, Teknologi Pembelajaran Landasan dan Aplikasinya, Penerbit Rineka Cipta, Jakarta.

Winkel, W.S., (2004), Psikologi Pengajaran, Penerbit Media Abadi., Yogyakarta.

Yamin, M., (2010), Kiat Membelajarkan Siswa, Penerbit Gaung Persada Press, Jakarta. 